\title{
Penggunaan Bahasa Verbal pada Kelompok Suporter Sepakbola Indonesia (Studi Etnografi Komunikasi pada Suporter The Jak Mania)
}

\author{
Martin Prasetyo $^{1}$ * Eko Digdoyo ${ }^{2}$ \\ ${ }^{1}$ Prodi Ilmu Komunikasi, FISIP UHAMKA, Jl. Limau II, Kebayoran Baru, Jakarta Selatan, Indonesia, 12130 \\ ${ }^{2}$ Prodi Ilmu Komunikasi, FISIP UHAMKA, Jl. Limau II, Kebayoran Baru, Jakarta Selatan, Indonesia, 12130 \\ * Email Korespondensi: ekodigdoyo77@ yahoo.co.id
}

Kata kunci:

Bahasa

Etnografi

Jakmania

Komunikasi

Keyword:

Communication

Etnografi

Jakmania

Language

\section{A B S T R A K}

Tujuan kajian ini adalah untuk mengetahui bagaimana bahasa verbal dipergunakan oleh kelompok suporter The Jak Mania. Penelitian ini menggunakan paradigma konstruktivime dan teori speech code. Teori ini digunakan untuk menjawab tentang keberadaan kode bicara dalam kelompok suporter The Jak Mania yang memiliki ciri khas yang membedakannya dengan kelompok lain. Pendekatan yang digunakan kualitatif dan jenis penelitian deskriptif. Teknik pengumpulan data m e g g u n a k a m: observasi partisipatif, wawancara mendalam, dan studi dokumentasi. Hasil penelitian ini menunjukkan bahwa suporter The Jak Mania sesungguhnya tidak menciptakan bahasa atau kode khas secara resmi, tetapi bahasa atau kode khas itu dibentuk oleh para pendiri, ketua umum, leader dan anggota untuk mempermudah mereka dalam berkomunkasi, sehingga menjadi efektif. Bahasa atau kode khas itu sering digunakan dan bisa bertahan, karena mereka memahami maknanya yang telah disepakati bersama. Dalam membuat bahasa dan kode khas tersebut, suporter The Jak Mania membuatnya dengan makna yang kreatif, inovatif dan mempunyai nilai motivasi.

\section{A B S T R A C T}

The purpose of this study is to find out how verbal language is used by The Jak Mania' supporter groups and forms of verbal language. This study uses a constructivism paradigm. The theory used in this research is speech code theory. This theory tries to answer the existence of a speech code in the group of supporters of The Jak Mania which has a characteristic that distinguishes it from other groups. The approach used in this study is qualitative, descriptive research type and using ethnographic communication methods. Data collection techniques for participant observation, in-depth interviews and documentation. The results of this study indicate that supporters of The Jak Mania actually do not officially issue specific languages or codes, but that specific language or codes are formed from the founders, chairmen, leaders and members to facilitate communication so that they become effective. Typical language or code is often used and can survive because of its meaning and mutual agreement. In making the distinctive language and code, supporters of The Jak Mania make it meaningfully creative, innovative and have motivational value.

\section{PENDAHULUAN}

Manusia sebagai mahluk sosial yang senantiasa berinteraksi dengan sesamanya, maka manusia membutuhkan komunikasi antara satu sama lain dalam kegiatan bersosialisasi. Berkomunikasi sebenarnya mengharapkan atau bertujuan terjadinya perubahan sikap atau tingkah laku orang lain untuk memenuhi harapan sebagaimana pesan tersebut disampaikan.

Salah satu faktor yang mendukung terjadinya komunikasi adalah bahasa. Bahasa adalah sebuah sistem, artinya bahasa itu dibentuk dalam sejumlah komponen yang berpola secara tetap dan dapat dikaidahkan (Chaer, 2010). Bahasa itu alat yang digunakan manusia untuk saling berkomunikasi atau berinteraksi, bisa lewat tulisan atau lisan dengan tujuan menyampaikan pikiran, gagasan, konsep atau perasaan kepada lawan bicara atau orang lain (Chaer, 1994). Pendapat tersebut diperkuat oleh Liliweri (2003) dan Litlejohn dan Karen (2011).

Dalam olahraga sepakbola, bahasa menjadi hal terpenting dikarenakan untuk berkomunikasi atau berinteraksi dalam 
suatu pertandingan sepakbola. Dalam lintasan sejarah sepakbola Indonesia dimulai sejak tahun 1894, saat Indonesia masih dijajah oleh pemerintah Hindia Belanda. Persatuan Sepakbola Indonesia Jakarta atau yang dikenal dengan nama Persija pada awalnya bernama VIJ (Voetbalbond Indonesia Jacatra) yang berdiri sejak 28 November 1928. Pada tahun 1997 saat Sutiyoso atau yang sering akrab dipanggil Bang Yos dilantik menjadi gubenur baru DKI Jakarta.

Bang Yos saat itu memiliki niatan untuk membangkitkan dan menghidupkan kembali sepakbola Jakarta dan mempunyai tim yang membanggakan warganya. Salah satu yang terjadi perubahan dalam hal suporter, tepat 19 desember 1997 kelompok suporter The Jak Mania berdiri dan mendukung kesebelasan sepakbola Persija Jakarta. Saat sekretariat The Jak Mania berada di GOR Soemantri, Kuningan dikarenakan Stadion Lebak Bulus digusur. Saat itu The Jak Mania sudah memiliki kordinator wilayah (Korwil) sebanyak 64 yang tersebar di beberapa wilayah Jakarta, Jawa Barat, Tangerang dan Jawa Tengah sedangkan untuk subkorwil hampir menyeluruh di berbagai wilayah Indonesia. Semakin banyaknya anggota The Jak Mania dari berbagai wilayah di Indonesia semakin banyak pula bahasa serta istilah-istilah dan kode-kode pembicaraan baru yang muncul dan dipergunakan.

Keberadaan kelompok suporter sepakbola menarik untuk diteliti, karena kelompok suporter sepakbola memiliki penggunaan bahasa yang tidak disadari membentuk suatu budaya baru. Di suporter sepakbola latar belakang budaya dapat menjadi hambatan berkomunikasi antar sesama, apalagi dalam perbedaan berbahasa, tetapi terciptanya bahasa yang dibuat mereka sendiri dalam sebuah kelompok suporter dapat menjadikan terciptanya persaudaraan dan kedekatan satu sama lain. Berdasarkan latarbelakang tersebut, maka masalah yang perlu dijawab dalam kajian ini adalah bagaimana penggunaan bahasa verbal pada kelompok suporter sepakbola Indonesia, studi etnografi komunikasi pada Suporter The Jak Mania?

Tujuan kajian ini adalah untuk menjawab masalah penggunaan bahasa verbal pada kelompok suporter sepakbola Indonesia, studi etnografi komunikasi pada Suporter The Jak Mania. Penulis mengambil obyek Suporter The Jak Mania, sebab suporter sepak bola memiliki fanatisme dalam bentuk etnis dan bahasa. Untuk itu dengan menggunakan paradigma konstruktivime dan pendekatan speech code theory. Pendekatan teori ini berusaha menjawab tentang keberadaan kode bicara dalam kelompok suporter The Jak Mania yang memiliki ciri khas yang membedakannya dengan kelompok lain.

\section{METODE PENELITIAN}

Dalam kajian ini, peneliti menggunakan pendekatan penelitian kualitatif. Data kualitatif adalah data yang berbentuk kata-kata, kalimat-kalimat, narasinarasi yang diuraikan berdasarkan studi kasus tertentu dan dilengkapi dengan makna-makna simbol tertentu. Data tersebut berhubungan dengan kategorisasi, karakteristik berwujud pertanyaan atau berupa kata-kata (Kriyantono, 2010).

Alasan peneliti menggunakan pendekatan kualitatif, sebab penelitian yang dilakukan tujuannya adalah untuk mengetahui realitas mengenai penggunaan bahasa verbal pada kelompok suporter The Jak Mania. Data yang tersusun diharapkan untuk menjelaskan fenomena-fenomena yang sedalam-dalamnya (kualitas) bukan banyaknya data (kuantitas), sehingga penelitian yang peneliti lakukan hanya bisa menggunakan penelitian kualitatif serta melalui pengumpulan data wawancara mendalam dan observasi dengan objek penelitian terkait Bungin (2007).

Penelitian tentang studi etnografi komunikasi terhadap penggunaan bahasa dalam kelompok suporter The Jak Mania umumnya masih jarang dilakukan oleh peneliti lain. Guna menghasilkan penelitian yang obyektif dan mendalam, maka seringkali peneliti turut melakukan aktivitas informan (participan observation). Hasil wawancara mendalam penulis dengan tiga informan diperkuat dengan dokumentasi yaitu berupa rekaman hasil wawancara dan berupa foto ketika melakukan wawancara. Peneliti melakukan observasi langsung dari tempat 
para anggota The Jak Mania berkumpul di Sekretariat The Jak Mania yang beralamat di Gor Soemantri Brodjonegoro dan di Stadion saat pertandingan Persija Jakarta (Patriot Candrabaga Bekasi).

Dapat disimpulkan bahwa bahasa atau kode khas kelompok suporter The Jak Mania itu tidak harus dipaksakan untuk mengerti karena bahasa itu mudah untuk dipahami dan diingat. Bahasa itu sangat beragam dan tidak hanya satu (Chaer, 1994). Bahasa didefinisikan sebagai seperangkat simbol, dengan aturan untuk mengkombinasikan simbol-simbol tersebut, yang digunakan dan dipahami suatu komunitas (Mulyana, 2008).

Dalam proses wawancara, penulis mengajukan beberapa pertanyaan, sehingga maksud dari bahasa verbal tersebut. Dengan adanya kelompok suporter The Jak Mania, penulis mendapatkan beberapa bahasa dan kode khas suporter The Jak Mania, seperti Sajete (Salam Jempol Telunjuk), Jak Angel, Rojali (Rombongan Jak Liar), Jakmania 12, Jak Mania Outsiders, Satu Jakarta Satu, SFO (Spirit From Outsider), Aing Persija, Jak Lapak. Semakin bertambahnya suporter The Jak Mania pasti bahas itu akan bertambah juga tetapi bahasa nantinya bertambah harus memiliki nilai kreatif, inovatif dan mempunyai nilai motivasi untuk Persija Jakarta dan The Jak Mania. Berikut ini adalah penjelasan contoh bentuk verbal berikut maknanya yang umum dipergukan oleh The Jak Mania.

\begin{tabular}{|c|c|l|}
\hline No & \multicolumn{1}{|c|}{ Bahasa verbal } & \multicolumn{1}{|c|}{ Maknanya } \\
\hline 1 & $\begin{array}{l}\text { Sajete (Salam } \\
\text { Jempol Telunjuk) }\end{array}$ & $\begin{array}{l}\text { Sajete ini } \\
\text { menjadi bahasa } \\
\text { serta salam } \\
\text { khas suporter } \\
\text { The Jak Mania } \\
\text { untuk saling } \\
\text { sapa }\end{array}$ \\
\hline 2 & Jak Angel & $\begin{array}{l}\text { Sebutan Jak } \\
\text { Mania bagi } \\
\text { kaum } \\
\text { perempuan di } \\
\text { suporter The Jak } \\
\text { Mania }\end{array}$ \\
\hline
\end{tabular}

\begin{tabular}{|c|c|c|}
\hline 3 & $\begin{array}{l}\text { Rojali (Rombongan } \\
\text { Jak Liar) }\end{array}$ & $\begin{array}{l}\text { Rojali } \\
\text { merupakan } \\
\text { suporter yang } \\
\text { dianggap } \\
\text { membuat resah } \\
\text { dan membuat } \\
\text { ulah yang } \\
\text { merugikan } \\
\text { Persija Jakarta } \\
\text { maupun The } \\
\text { Jak Mania itu } \\
\text { sendiri. }\end{array}$ \\
\hline 4 & Jak Mania 12 & $\begin{array}{l}\text { Merupakan } \\
\text { sebuah bentuk } \\
\text { apresiasi dan } \\
\text { penghargaan } \\
\text { yang diberikan } \\
\text { oleh Persija } \\
\text { Jakarta untuk } \\
\text { suporternya. } \\
\text { Nomor } \\
\text { punggung } \\
12 \text { pun tidak } \\
\text { dipakai oleh } \\
\text { pemain Persija } \\
\text { Jakarta, karena } \\
\text { telah } \\
\text { sepenuhnya } \\
\text { menjadi milik } \\
\text { The Jak Mania. }\end{array}$ \\
\hline
\end{tabular}




\begin{tabular}{|c|c|c|}
\hline 5 & Satu Jakarta Satu & $\begin{array}{l}\text { Kalimat sebuah } \\
\text { ajakan untuk } \\
\text { menyatukan } \\
\text { seluruh anak } \\
\text { muda Jakarta } \\
\text { yang sering } \\
\text { terlibat tawuran } \\
\text { antar sekolah, } \\
\text { antar wilayah } \\
\text { padahal kita } \\
\text { semua sama- } \\
\text { sama berasal } \\
\text { dari satu } \\
\text { wilayah, yakni } \\
\text { Kota Jakarta. } \\
\text { Satu Jakarta } \\
\text { Satu juga } \\
\text { sebuah kalimat } \\
\text { untuk } \\
\text { menyatukan The } \\
\text { Jak Mania yang } \\
\text { terdiri dari } \\
\text { berbagai } \\
\text { kalangan } \\
\text { masyarakat di } \\
\text { Jakarta yang } \\
\text { heterogen dan } \\
\text { sekaligus } \\
\text { memotivasi ke } \\
\text { Persija Jakarta } \\
\text { supaya menjadi } \\
\text { juara satu. }\end{array}$ \\
\hline 6 & Jak Mania Outsiders & $\begin{array}{l}\text { Pendukung } \\
\text { Persija Jakarta } \\
\text { yang berada di } \\
\text { luar kota } \\
\text { Jakarta yang } \\
\text { setia dalam } \\
\text { mendukung } \\
\text { Persija Jakarta } \\
\text { bertanding }\end{array}$ \\
\hline 7 & $\begin{array}{l}\text { SFO (Spirit From } \\
\text { Outsiders) }\end{array}$ & $\begin{array}{l}\text { Untuk } \\
\text { membakar } \\
\text { semangat dalam } \\
\text { mendukung } \\
\text { Persija Jakarta } \\
\text { walaupun bukan } \\
\text { berdomisili di } \\
\text { wilayah Jakarta. }\end{array}$ \\
\hline
\end{tabular}

\begin{tabular}{|c|c|c|}
\hline 8 & Aing Persija & $\begin{array}{l}\text { Kata Aing } \\
\text { Persija } \\
\text { memiliki } \\
\text { makna, yakni } \\
\text { identitas untuk } \\
\text { The Jak Mania } \\
\text { yang berasal } \\
\text { dari wilayah } \\
\text { Jawa Barat, } \\
\text { walaupun } \\
\text { notabene } \\
\text { wilayah mereka } \\
\text { masih } \\
\text { merupakan } \\
\text { wilayah } \\
\text { mayoritas } \\
\text { pendukung } \\
\text { Persib Bandung } \\
\text { tapi mereka } \\
\text { secara tidak } \\
\text { sembunyi- } \\
\text { sembunyi } \\
\text { menyatakan } \\
\text { dukungannya } \\
\text { terhadap Persija } \\
\text { Jakarta }\end{array}$ \\
\hline 9 & Jak Lapak & $\begin{array}{l}\text { Jak Lapak ini } \\
\text { suporter Persija } \\
\text { Jakarta yang } \\
\text { menawarkan } \\
\text { atribut atau } \\
\text { pernak-pernik } \\
\text { bertemakan } \\
\text { Persija Jakarta } \\
\text { serta The Jak } \\
\text { Mania yang } \\
\text { biasanya berada } \\
\text { di sekitaran } \\
\text { Stadion saat } \\
\text { Persija Jakarta } \\
\text { bertanding, } \\
\text { sedangkan saat } \\
\text { Persija Jakarta } \\
\text { tidak } \\
\text { bertanding, Jak } \\
\text { Lapak ini } \\
\text { berjualan di } \\
\text { tokonya } \\
\text { masing-masing } \\
\text { yang tersebar di } \\
\text { wilayah } \\
\text { Jabodetabek. }\end{array}$ \\
\hline
\end{tabular}




\section{HASIL DAN PEMBAHASAN}

Speech Code Theory

Teori ini dilandaskan atas kajian etnografi kebudayaan. Melalui pola pikir yang dikembangkan yaitu setiap komunitas memiliki ciri khas yang membedakannya dengan komunitas lain, salah satunya yaitu kode berbicara dalam proses komunikasi (Goldberg, 2006). Teori ini juga berusaha menjawab tentang keberadaan kode berbicara dalam suatu budaya, cara ditemukannya dan bagaimana maknanya (Effendy, 2007).

Sebuah penggambaran dua keluarga dari dua komunitas yang berbeda merupakan perumpamaan awal yang bisa mendapatkan pencitraan utuh tentang teori kode berbicara menurut Gery Philipsen ini. Penelitian yang dilakukan selama kurang tiga tahun ini ia melibatkan dirinya pada komunitas pekerja di Chicago, Teamsterville. Hasilnya ia menemukan adanya kekhasan, dalam hal ini penggunaan dan pengucapan bahasa, yang digunakan oleh komunitas Teamsterville yang sangat berbeda sekali dengan kebiasaan umum yang dengan komunitas Nacirema (dalam Griffin, 2012).

\section{Kode Berbicara}

Philipsen mengemukakan lima proposisi yang dapat menjelaskan tentang teori ini, yaitu: kekhasan kode berbicara, substansi kode berbicara, interpretasi kode berbicara, pemetaan kode berbicara serta kekuatan kode berbicara.

1. Proposisi pertama

Dalam kekhasan kode berbicara philipsen menegaskan bahwa setiap budaya yang terbentuk, baik itu budaya yang ada di komunitas ataupun lokal maupun komunitas umum, memiliki kode berbicara tertentu. Ketika anda memasuki komunitas kalangan pekerja Teamsterville, Philipsen menemukan adanya kosakata, ungkapan, maupun tata bahasa yang sangat sama sekali berbeda dengan apa yang selama ini dipahaminya bahkan kebiasaan yang berlaku umum. Salah satunya adalah kebiasaan penduduk di Teamsterville untuk tidak memulai sebuah percakapan tanpa terlebih dahulu memastikan status dari lawan bicaranya. Mereka harus meyakini bahwa atau setidaknya mengetahui latar belakang lawan bicaranya, dari etnis apa, status sosialnya hingga tempat tinggalnya.

2. Proposisi kedua

Sementara dalam substansi kode berbicara, Philipsen menekankan adanya pengaruh psikologi, sosiologi maupun retorika yang membangun kode berbicara itu. Psikologi menurut Philipsen, tiaptiap kode berbicara "pokok pembicaraan" alami tentang individu secara khusus. Sosiologi, Philipsen menulis bahwa suatu kode berbicara menyediakan suatu sistem jawaban tentang hubungan antara pribadi dan orang lain, yang dapat dilihat/dicari dan sumber daya simbolis apa yang dapat dengan efektif dalam mebcari hubungan itu. Dalam konteks retorika, Philipsen menggunakannya pengertian penemuan kebenaran yang ganda dan pendekatan membujuk. Hal ini dapat dijelaskan bahwa perilaku individu dalam komunitas Teamsterville dibentuk secara unik oleh kebiasaan-kebiasaan yang ada dalam komunitas tersebut. Gambaran pribadi yang "sempurna" bagi komunitas Teamsterville apabila ia mematuhi/mengikuti aturan-aturan yang berlaku dikomunitas ini. Ada pembagian kelas yang sangat mencolok di komunitas ini. Sementara bagi komunitas Nacirema individu memiliki kebiasaan yag unik dan berbeda dari individu lainnya. Meski secara umum ada aturan-aturan sosial yang berlaku, akan tetapi individu berkembang sesuai dengan caranya tersendiri. Individu dinilai tidak dari penampakan luar semata melainkan dari apa yang terpancar dari dalam individu itu sendiri.

3. Proposisi ketiga 
Philipsen menginterpretasi kode berbicara sebagai satu kesatuan yang utuh. Artinya kode berbicara ini akan berlaku apabila ada kesamaan persepsi antara komunikan dan komunikator. Kode berbicara ini akan muncul apabila ada interaksi yang sangat efektif antara komunikan dan komunikator. Artinya Philipsen menegaskan bahwa interpretasi dari kekhasan kode berbicara itu tergantung dari hubungan di antara dua individu atau lebih yang didukung dengan adanya kedekatan, keterbukaan, dan dukungan pembicaraan. Dengan demikian, kode berbicara akan berlaku ketika "apa yang disampaikan"e sudah dipahami oleh individu-individu yang saling berinteraksi tersebut; berasal dari lingkungan sosial maupun budaya yang sama.

4. Proposisi keempat

Selanjutnya ketika berbicara tentang pemetaan kode berbicara, Philipsen menggambarkan bahwa kode berbicara itu sendiri muncul dari pencitraan publik atau komunitas yang saling berinteraksi satu dengan yang lainnya. Kode berbicara dengan pengertian lain dipetakan dalam pembicaran itu sendiri.

5. Proposisi kelima

Philipsen menegaskan bahwa kode berbicara dengan segala yang dimaknainya dalam kondisi tertentu akan mampu memprediksi, memberikan gambaran menjelaskan hingga mengontrol keadaan dari proses komunikasi.

\section{Etnografi Komunikasi}

Dalam buku Metode Etnografi Komunikasi Suatu Pengantar dan Contoh Penelitiannya, Kuswarno (2011:11) menjelaskan mengenai etnografi komunikasi. Studi etnografi adalah pengembangan dari antropologi linguistik yang dipahami dalam konteks komunikasi. Studi ini diperkenalkan pertama kali oleh Dell Hymes pada tahun 1962, sebagai kritik terhadap ilmu linguistik yang terlalu memfokuskan diri pada fisik bahasa saja. Definisi etnografi komunikasi itu sendiri adalah pengkajian peranan bahasa dalam perilaku komunikaif suatu masyarakat, yaitu cara-cara bagaimana bahasa dipergunakan dalam masyarakat yang berbeda-beda kebudayaannya (Goldberg, 2006).

\section{Analisis Kaitan Etnografi Komunikasi pada The Jak Mania}

Dalam buku Metode Etnografi Komunikasi Suatu Pengantar dan Contoh Penelitiannya, Kuswarno (2011:11) menjelaskan mengenai etnografi komunikasi. Studi etnografi adalah pengembangan dari antropologi linguistik yang dipahami dalam konteks komunikasi. Studi ini diperkenalkan pertama kali oleh Dell Hymes pada tahun 1962, sebagai kritik terhadap ilmu linguistik yang terlalu memfokuskan diri pada fisik bahasa saja. Definisi Etnografi komunikasi itu sendiri adalah pengkajian peranan bahasa dalam perilaku komunikaif suatu masyarakat, yaitu cara-cara bagaimana bahasa dipergunakan dalam masyarakat yang berbeda-beda kebudayaannya (Wirawan, 2001).

Berdasarkan hasil penelitian terdahulu (Ismawati (2007) lebih fokus pada Adaptasi Komunikasi Verbal pada Mahasiswa Pendatang terhadap Etnis Sunda dalam Mewujudkan Komunikasi Antar Prbadi yang Efektif. Sementara itu, Bagja (2009) lebih menyoroti Etnografi Komunikasi terhadap Penggunaan Bahasa dalam Kaskus (Forum Jual Beli). Dari kedua hasil penelitian tersebut berkaitan dengan etnografi komunikasi dalam kontek penelitian ini.

Untuk itu, komunikasi yang dilakukan oleh kelompok suporter The Jak Mania adalah dengan menggunakan bahasa atau kode khas seperti, Sajete (Salam Jempol Telunjuk), Jak Angel (JA), Rojali (Rombongan Jak Liar), Jakmania12, Jakmania Outsiders (JO), Satu Jakarta Satu (SJS), Spirit From Outsiders (SFO), Aing Persija (AJ), da n Jak Lapak (JL).

Seluruh kegiatan komunikasi tersebut merupakan kegiatan yang telah biasa mereka lakukan ketika bertemu dengan teman-teman The Jak Mania lainnya atau saat sedang berintreaksi di media sosial. Jika mereka berada di lingkungan sehari-hari 
menggunakan bahasa Indonesia dan bahasa pergaulan Jakarta yang mudah dipahami oleh lawan bicaranya, sedangkan untuk Jak Mania Outsiders yang berasal dari wilayah geografis yang sama akan berkomunikasi dengan bahasa daerah asalnya.

Komunikasi The Jak Mania yang terbilang dinamis, komunikatif dan efektif dapat mempermudah dalam proses komunikasi. Bahasa ini digunakan dan disepakati bersama oleh kelompok suporter The Jak Mania, pada akhirnya bahasa ini berkembang dan terus memproduksi bahasabahasa yang baru sesuai dengan perkembangan zaman.

Sebagaimana dikemukakan oleh Vardiansyah (2008), isu dasar etnografi komunikasi adalah bahasa, budaya dan komunikasi. Ketiga isu tersebut menurut penulis sesuai dengan apa yang dikaji di dalam kelompok suporter The Jak Mania. Ketika berbicara mengenai bahasa dan kode khas yang terdapat di suporter The Jak Mania, akan muncul dalam benak seseorang bahasa yang terbilang unik dan komunikatif. Bahasa tersebut digunakan dalam komunikasi antar The Jak Mania. Cara berkomunikasi dengan bahasa yang unik, membuat kelompok suporter The Jak Mania memiliki karakter yang khas dan memiliki budaya sendiri.

\section{Analisis Speech Code Theory (Teori Kode Bicara) dan Hubungannya dengan Kelompok Suporter The Jak Mania}

Penulis menggunakan Speech Code Theory sebagai grand theory dalam penelitian ini. Teori kode bicara dilandaskan atas kajian etnografi atau kebudayaan. Melalui pola pikir yang dikembangkan yaitu setiap komunitas memiliki ciri khas yang membedakannya dengan komunitas yang lain, salah satunya yaitu kode bicara dalam proses komunikasi. Philipsen menemukan lima proposisi yang dapat menjelaskan tentang teori tersebut, yaitu; pada proposisi pertama kekhasan kode berbicara philipsen menegaskan bahwa setiap budaya yang terbentuk, baik itu budaya yang ada di komunitas ataupun lokal maupun komunitas umum, memiliki kode berbicara tertentu (Philipsen, dalam Griffin, 2012).

Dalam hal ini kelompok suporter The Jak Mania juga memiliki kekhasan kode bicara seperti penggunaan kata atau istilah- istilah khas seperti Sajete (Salam Jempol Telunjuk), Jak Angel (Suporter wanita pendukung Persija Jakarta), Rojali (Rombongan Jak Liar), Jakmania12 (untuk The Jak Mania sebagai pemain Persija ke12), Jakmania Outsiders (sebutan The Jak Mania yang berdomisili diluar Jakarta), Aing Persija (Saya Persija). Kode- kode tersebut merupakan contoh kode khas kelompok suporter The Jak Mania dalam berkomunikasi.

Pada proposisi kedua, khususnya substansi kode berbicara, Philipsen menekankan adanya pengaruh psikologi, sosiologi maupun retorika yang membangun kode berbicara itu (menurut Philipsen dalam Griffin, 2012: 424). Contohnya dalam sosiologi yang berhubungan dengan bahasa ini yakni akan menjadi pembendaharaan kosa kata bahasa baru dikalangan masyarakat. Untuk psikologi, kode SFO atau Aing Persija ini akan menjadi tambahan semangat yang di bawa oleh The Jak Mania yang berdomisili diluar Jakarta untuk mendukung Persija Jakarta bertanding. Untuk retorika, gaya bahasa yang diucap oleh pendiri dan ketua maupun leader akan menjadi bahasa yang cepat tersebar karena mudah diterima oleh The Jak Mania. Kemudia pada proposisi ketiga, Philipsen menginterpretasi kode berbicara sebagai satu kesatuan yang utuh. Artinya kode berbicara ini akan berlaku apabila ada kesamaan persepsi antara komunikan dan komunikator (Philipsen dalam Griffin, 2012).

Bahasa dan kode khas kelompok suporter The Jak Mania yang dapat disalahartikan oleh masyarakat atau kelompok lain yang belum paham yaitu Rojali (Rombongan Jak Liar) menjadi rokok jarang beli atau rombongan jarang beli. Selanjutnya pada proposisi keempat, ketika berbicara tentang pemetaan kode berbicara, Philipsen menggambarkan bahwa kode berbicara itu sendiri muncul dari pencitraan publik atau komunitas yang saling berinteraksi satu dengan yang lainnya (menurut Philipsen dalam Griffin, 2012).

Pemetaan kode bicara dalam kelompok suporter The Jak Mania contohnya adalah kode Rojali yang dapat menjadikan citra buruk untuk Persija Jakarta dan The Jak Mania. Kode Jak Mania Outsiders, SFO dan Aing Persija ini adalah kode khas untuk 
para The Jak Mania yang berdomisili diluar kota Jakarta. Jak Lapak juga kode khas dari kelompok suporter The Jak Mania yang berjualan merchandise di sekitaran Stadion. Bahasa-bahasa tersebut hasil dari interaksi antar The Jak Mania yang senantiasa menggunakan kode tersebut.

Kemudian proposisi kelima, Philipsen menegaskan bahwa kode berbicara dengan segala yang dimaknainya dalam kondisi tertentu akan mampu memprediksi, memberikan gambaran, menjelaskan hingga mengontrol keadaan dari proses komunikasi (menurut Philipsen dalam Griffin, 2012). Melalui kode-kode khas kelompok suporter The Jak Mania tersebut proses komunikasi menjadi mudah, effisien, efektif dan komunikatif karena bagi mereka para The Jak Mania menggunakan istilah tersebut lebih menyenangkan karena lebih praktis.

\section{Kesimpulan}

Berdasarkan pembahasan hasil penelitian studi etnografi komunikasi terhadap penggunaan bahasa verbal pada kelompok suporter sepakbola Indonesia (studi etnografi komunikasi pada suporter The Jak Mania) dapat ditarik kesimpulan sebagai berikut:

1. Dalam bahasa sehari-hari menggunakan bahasa Indonesia, bahasa pergaulan Jakarta dan bahasa daerah untuk The Jak Mania yang berada di luar kota Jakarta. Untuk berinteraksi dan berkomunikasi sesama The Jak Mania menggunakan kode bicara untuk mempererat kebersamaan dan memperbesar rasa persaudaraan.

2. Suporter The Jak Mania sendiri tidak mengeluarkan bahasa atau kode khas secara resmi tetapi bahasa atau kode khas itu bermunculan dari para pendiri, ketua umum, leader dan anggota untuk mempermudah dalam berkomunkasi sehingga menjadi efektif. Bahasa atau kode khas itu sering digunakan dan bisa bertahan karena paham dengan maknanya dan disepakati bersama apalagi mereka sama-sama merasakan makna bahasa tersebut dalam menyaksikan pertandingan Persija Jakarta.
3. Munculnya dan berkembangnya bahasa dan kode-kode khas kelompok suporter The Jak Mania bukanlah suatu yang negatif dan merusak bahasa Indonesia selama digunakan oleh anggota kelompok untuk berkomunikasi dengan sesama anggota kelompok demi lancarnya komunikasi antar The Jak Mania.

4. Bahasa kelompok suporter The Jak Mania termasuk pemodern bahasa yaitu bertambahnya pembendaharaan kosa kata dan pengakroniman. Adanya bahasa dan kode-kode khas tersebut dapat menambah pembendaharaan bahasa Indonesia.

5. Dalam membuat bahasa dan kodekode khas tersebut bisa bertambah, tetapi bahasa itu harus yang kreatif, inovatif dan mempunyai nilai motivasi.

\section{Rekomendasi}

1. Kepada peneliti berikutnya diharapkan muncul penelitian serupa dengan menggunakan pendekatan kajian lainnya, sehingga dapat menjadi salah satu bobot pengembangan keilmuan, khususnya ilmu komunikasi.

2. Bagi kreator atau inisiator kreasi bahasa suporter, diharapkan memunculkan bahasa suporter yang positif, tanpa merugikan kelompok atau etnis tertentu, sehingga tidak terjadi konflik yang berlatar belakang bahasa suporter.

3. Melalui komunikasi kajian etnografi komunikasi, diharapkan dapat memperkuat ikatan suporter yang tidak menimbulkan fanatisme negatif terhadap kelompok suporter lain.

\section{References}

Bagja, Komaruddin. 2009. Etnografi Komunikasi terhadap Penggunaan Bahasa dalam Kaskus (Forum Jual Beli), Skripsi. Jakarta: UHAMKA.

Bungin, Burhan. 2007. Penelitian Kualitatif Komunikasi, Ekonomi, Kebijakan Publik, dan Ilmu Sosial Lainnya. Jakarta: Kencana Prenada Media Group.

Bungin, Burhan. 2013. Sosiologi Komunikasi: Teori, Paradigma, dan Diskursus Teknologi Komunikasi di Masyarakat. 
Jakarta: Kencana Prenada Media Group. Chaer, Abdul. 1994. Linguistik Umum, Jakarta: PT. Rineka Cipta.

Chaer, Abdul \& Agustina, Leonie. 2010. Sosiolinguistik Perkenalan Awal, Jakarta: PT. Rineka Cipta.

Effendy, Onong Uchjana. 2007. Ilmu Teori dan Filsafat Komunikasi. Bandung: PT. Citra Aditya Bakti.

Goldberg, Alvin A. 2006. Komunikasi Kelompok : Proses Diskusi dan Penerapannya. Jakarta: Universitas Indonesia.

Griffin, EM. 2012. A first look at Communication Theory, New York: Hill Companies.

Ismawati. Ainul. 2007. Adaptasi Komunikasi Verbal pada Mahasiswa Pendatang terhadap Etnis Sunda dalam Mewujudkan Komunikasi Antar Prbadi yang Efektif (Studi Kasus Mahasiswa Pendatang STISI di Pondok Aswaja Kiara Condong, Bandung, Jawa Barat. Skripsi. Jakarta: UHAMKA.

Kriyantono, Rachmat. 2010. Teknik Praktis Riset Komunikasi, Jakarta: Kencana Prenada
Media Group.

Kuswarno, Engkus. 2011. Etnografi Komunikasi Suatu Pengantar dan Contoh Penelitiannya. Bandung: Widya Padjajaran.

Liliweri, Alo. 2003. Makna Budaya Dalam Komunikasi Antarbudaya. Yogyakarta: LKis.

Litlejohn, Stephen \& Foss, Karen. 2011. Teori Komunikasi: Theories of Human Communication. Jakarta: Salemba Humanika.

Mulyana, Deddy \& Rakhmat, Jalaluddin. 1990. Komunikasi Antarbudaya. Bandung: PT. Remaja Rosdakarya.

Mulyana, Deddy. 2008. Ilmu Komunikasi Suatu Pengantar. Bandung: PT. Remaja Rosdakarya.

Vardiansyah, Dani. 2004. Pengantar Ilmu Komunikasi. Bogor: Ghalia Indonesia.

Vardiansyah, Dani. 2008. Filsafat Ilmu Komunikasi Suatu Pengantar. Jakarta: PT. Indeks.

Wirawan, Sarlito. 2001. Psikologi Sosial. Jakarta: Balai

Pustaka.

2020 Oleh authors. Lisensi KOMUNIKA: Jurnal Ilmu Komunikasi, Uhamka, Jakarta. Artikel ini bersifat open access yang didistribusikan di bawah syarat dan ketentuan Creative Commons Attribution (CC-BY) license (http://creativecommons.org/licenses/by/4.0/) 